\title{
THE EFFECT OF CYCLOPHOSPHAMIDE ON SENDAI VIRUS INFECTION OF MICE
}

\author{
T. W. E. Robinson, R. J. R. Cureton and R. B. Heath \\ Departments of Bacteriology and Pathology, \\ St Bartholomew's Hospital, London

\section{Plates VII-IX}

IT is well recognised that immunosuppressant therapy with agents such as $\mathrm{X}$-rays, cytotoxic drugs and steroids increases susceptibility to infections. This is particularly true in relation to infections caused by bacteria and fungi, but much less is known about the effect of these treatments on virus infections. It is, however, well known that patients receiving immunosuppressive treatment should not be vaccinated against smallpox because of the risks of complications such as generalised vaccinia and vaccinia gangrenosa. Some of these patients have experienced severe and even fatal illnesses when infected with varicellazoster virus (Haggerty and Eley, 1956; Merselis, Kaye and Hook, 1964). It has also been observed that serious infections with cytomegalovirus occur in patients receiving immunosuppressant drugs after homotransplantation surgery (Hill et al., 1967).

The experiments to be described in this paper were undertaken in an attempt to obtain information on the effect of immunosuppressant drugs on a simple viral respiratory infection. Sendai virus infection of the lungs of mice was used as the model because normally it fails to produce obvious illness in these animals although it damages the respiratory mucous membranes (Robinson, Cureton and Heath, 1968). The mice were treated with cyclophosphamide since it had previously been shown that this drug depresses interferon production in vivo (Robinson and Heath, 1968) in addition to its inhibition of antibody formation (Stender, Strauch and Winter, 1961).

\section{MATERIALS AND METHODS}

Virus. The Sendai strain of parainfluenza 1 virus was used. It was propagated in the allantoic cavity of 10-day-old embryonated hen's eggs.

Infection of mice. Swiss albino mice of $20-25 \mathrm{~g}$ were used; in all the experiments, they received $10^{5}$ EID50 of virus intranasally. The methods of inoculation and sampling and the histological procedures employed have been described previously (Robinson et al., 1968).

Assay methods. Monkey kidney tissue cultures were used for determining virus titres. Interferon assays were performed in mouse " $L$ " cells challenged with vesicular stomatitis virus. The haemagglutination-inhibition test was used for the determination of antibody titres. Details of all these procedures have been described previously (Robinson $e t$ al.).

Cyclophosphamide. The drug was administered subcutaneously to the mice in $1.0-\mathrm{ml}$

Received 31 July 1968 ; accepted 24 Sept. 1968.

3. MED. MICROBIOL.-VOL. 2 (1969) 
volumes. A dose of $200 \mathrm{mg}$ per $\mathrm{kg}$ was given to each mouse on the $1 \mathrm{st}$ and 5 th days after infection unless otherwise indicated in the text.

Bacteriology. Lung suspensions were prepared by maceration in chilled broth and samples were cultured aerobically on blood agar plates at $37^{\circ} \mathrm{C}$.

\section{RESULTS}

The experimental procedure consisted of infecting batches of mice with Sendai virus and treating half of them with cyclophosphamide. Two additional control groups were included in each experiment: one consisted of uninfected mice that were treated with cyclophosphamide; these served as a check on the toxicity of the drug and also excluded the possibility that any observed pathological changes were due to activation of latent organisms by the drug. The second control group consisted of mice that received no treatment of any kind; these served to exclude the possibility that any observed abnormalities had arisen spontaneously.

At various intervals after infection, groups of 6 mice were killed and their lungs were removed for macroscopic and microscopic examination, for bacteriological tests and for estimation of virus and interferon titres. Blood was also obtained at these times for antibody assays and white blood cell counts.

\section{Macroscopic changes}

It was found that Sendai infection in cyclophosphamide-treated mice was dramatically different from that in the untreated infected controls. The latter animals, as stated previously (Robinson et al.), appeared perfectly normal, whereas those treated with cyclophosphamide became ill during the $2 \mathrm{nd}$ wk of the infection and sometimes died. The cause of the illness was found to be the development of lung consolidation (fig. 1). The consolidation was similar to that produced by influenza viruses in normal mice, but was not observed as frequently, and was generally not so extensive as that produced by welladapted influenza strains. In all of the experiments it was noted that out of 87 infected mice given cyclophosphamide 70 per cent. developed lesions, whereas the drug produced lesions in only 5 out of 39 uninfected mice and all these lesions were seen in a single batch of mice. In these experiments, no lesions were seen in the infected untreated mice or in the mice that received neither virus nor drug. The results of a typical experiment are shown in table I. The commonest lesion seen was a generalised red mottling of the lungs (scored as \pm ), but 7 mice had frank consolidation of the lobes and 5 were found dead with total consolidation.

A more objective way of assessing the effect of cyclophosphamide on the lung changes was simply to weigh the lungs of groups of 5 mice killed at various intervals after the infection; the results of such an experiment are shown in table II. As described previously (Robinson et al.), the Sendai infection normally increases the weight of the lungs by about 50 per cent. by the 5 th day. When the infected mice are treated with cyclophosphamide, a further increase in weight occurs during the $2 \mathrm{nd}$ wk of the infection, the lungs eventually 
weighing more than twice as much as those of the uninfected controls. These results must be taken to indicate only the minimum increase in weight of the lungs since mice found dead with total lung consolidation were deliberately excluded.

TABLE I

Degrees of pneumonic consolidation observed in groups of Sendai virus-infected mice given varying doses of cyclophosphamide

\begin{tabular}{|c|c|c|c|c|c|c|c|c|}
\hline \multirow{2}{*}{$\begin{array}{l}\text { Dose of } \\
\text { cyclophosphamide } \\
(\mathrm{mg} \text { per } \mathrm{kg})^{*}\end{array}$} & \multirow{2}{*}{$\begin{array}{c}\text { Number of } \\
\text { mice } \\
\text { infected }\end{array}$} & \multicolumn{7}{|c|}{$\begin{array}{l}\text { Number of mice showing the } \\
\text { lung lesion score } \dagger\end{array}$} \\
\hline & & 0 & \pm & 1 & 2 & 3 & 4 & 5 \\
\hline $\begin{array}{r}400 \\
200 \\
100 \\
50 \\
0\end{array}$ & $\begin{array}{r}10 \\
10 \\
5 \\
5 \\
5\end{array}$ & $\begin{array}{l}3 \\
2 \\
1 \\
3 \\
5\end{array}$ & $\begin{array}{l}2 \\
2 \\
3 \\
2 \\
0\end{array}$ & $\begin{array}{l}1 \\
3 \\
1 \\
0 \\
0\end{array}$ & $\begin{array}{l}2 \\
0 \\
0 \\
0 \\
0\end{array}$ & $\begin{array}{l}0 \\
0 \\
0 \\
0 \\
0\end{array}$ & $\begin{array}{l}0 \\
0 \\
0 \\
0 \\
0\end{array}$ & $\begin{array}{l}2 \\
3 \\
0 \\
0 \\
0\end{array}$ \\
\hline
\end{tabular}

* Mice were given the stated dose of drug on the 1st day after infection.

$\dagger$ Lungs were examined either at the time of death or after killing on the 14th day after infection. The scoring method of Horsfall (1939) was used.

TABLE II

Effect of cyclophosphamide on the lung weights of Sendai virus-infected mice

\begin{tabular}{|c|c|c|c|c|c|c|c|c|c|c|}
\hline \multirow{2}{*}{\multicolumn{6}{|c|}{ Experimental group $\dagger$}} & \multicolumn{5}{|c|}{ Mean lung weight $(g) *$ on day } \\
\hline & & & & & & \multirow{2}{*}{$\begin{array}{c}0 \\
0 \cdot 14\end{array}$} & \multirow{2}{*}{$\begin{array}{l}3 \\
\ldots\end{array}$} & \multirow{2}{*}{$\begin{array}{r}5 \\
\ldots \\
\ldots\end{array}$} & \multirow{2}{*}{$\begin{array}{l}10 \\
\ldots\end{array}$} & \multirow{2}{*}{$\begin{array}{c}13 \\
0 \cdot 16\end{array}$} \\
\hline 1. Untreated controls & & & $\cdot$ & . & • & & & & & \\
\hline 2. Virus-infected only & . & & $\cdot$ & . & • & $\ldots$ & $0 \cdot 17$ & $0 \cdot 21$ & $0 \cdot 20$ & $0 \cdot 19$ \\
\hline \multicolumn{6}{|c|}{ 3. Virus-infected and cyclophosphamide-treated } & $\ldots$ & $0 \cdot 18$ & $0 \cdot 20$ & $0 \cdot 23$ & $0 \cdot 37$ \\
\hline
\end{tabular}
mice.

* Each estimation represents the mean weight of pairs of lungs obtained from a subgroup of 5

$\dagger$ Sendai virus was administered to groups 2 and 3 on day 0 . Cyclophosphamide (200 mg per kg) was given to group 3 on the 1 st and 5 th days after infection.

\section{Microscopic changes}

Up to the $3 r d$ day, the changes in the cyclophosphamide group were similar to those described in the lungs affected by virus inoculation alone (Robinson et al.). No appreciable difference could be detected in the degree of mucosal damage, the intensity of the initial inflammatory response, the component cells or the anatomical distribution of the inflammatory infiltration and exudate.

By the 5th day the intensity of the inflammatory reaction has built up to a level that corresponds closely with that seen in the untreated virus infection, but slight differences can be detected (fig. 2). The bronchial mucous membranes 
show more evidence of damage with more striking loss of cilia, more disintegration of the columnar epithelium and an apparently higher incidence of mitoses. The bronchial and peribronchial inflammatory infiltration seems to remain more polymorphic in character and although polymorphs have apparently migrated in considerable numbers, there is nevertheless a high proportion of these cells still to be seen in the bronchial infiltration. Pyknotic degeneration of these cells is striking. The surrounding alveoli also show differences from those of the lungs affected by virus infection only; there is a relatively greater thickening and cellularity of the capillary walls, some oedema is beginning to appear in the alveolar spaces and some large mononuclear cells are present in the alveoli. It was not possible to determine the origin of these cells, but many show phagocytic activity. No fibrin can be detected in the alveolar exudate.

The differences between the two groups of lungs become even more obvious by the 10th day. In the virus-affected but otherwise untreated mice the accumulation of mononuclear cells showing a pyroninophilic cytoplasm is the most striking feature of the lung pathology. In the cyclophosphamidetreated infected mice, however, these cells are scarcely in evidence and polymorph neutrophils still comprise the overwhelming proportion of the inflammatory cells both around the bronchi and arteries and also in the alveolar fields (fig. 3). Here, at this stage, oedema fluid exudate, numero us pyknotic degenerate polymorphs and some large mononuclear phagocytes are found in the alveoli over extensive areas (figs. 4 and 5) but these features never assume the picture of a bacterial pneumonia. In all areas there is marked thickening of the cellular alveolar walls and connective-tissue septa, which is regarded as typical of virus infection. Gram stains reveal an occasional organism but no sign of true bacterial invasion. A few coliform organisms were usually isolated from the lung suspensions of all the control groups, but significantly greater numbers were isolated from the infected and cyclophosphamide-treated group. Because of this, the possibility cannot be excluded that bacteria had played some small part in the pneumonic process.

By the 13th day the picture is still strikingly different from that seen in the untreated mice and may be described simply as an extension of the changes described for the 10th day (figs. 6 and 7). At this stage, however, some small focal collections of mononuclear cells can be found in the bronchial walls and these show a pyroninophilic cytoplasm in the Unna-Pappenheim sections; it therefore appears that these cells are considerably retarded in their appearance and are considerably reduced in numbers compared with the cell response in mice not treated with cyclophosphamide. Polymorph exudate is still continuing into the bronchi and the mucosa still shows continuing signs of damage together with active regeneration.

\section{Virus assay}

The effect of cyclophosphamide on virus growth in the lungs is shown in fig. 8. It can be seen that virus growth in the treated animals proceeded normally for the first 5 days of the infection. However, from the 5th day onwards, there was a marked difference in the growth of virus in the two groups 
of mice. The virus was effectively eliminated from the lungs of the untreated mice, but persisted in those that were being treated with cyclophosphamide. The effect was observed with doses of drug that varied from 50 to $400 \mathrm{mg}$ per $\mathrm{kg}$.

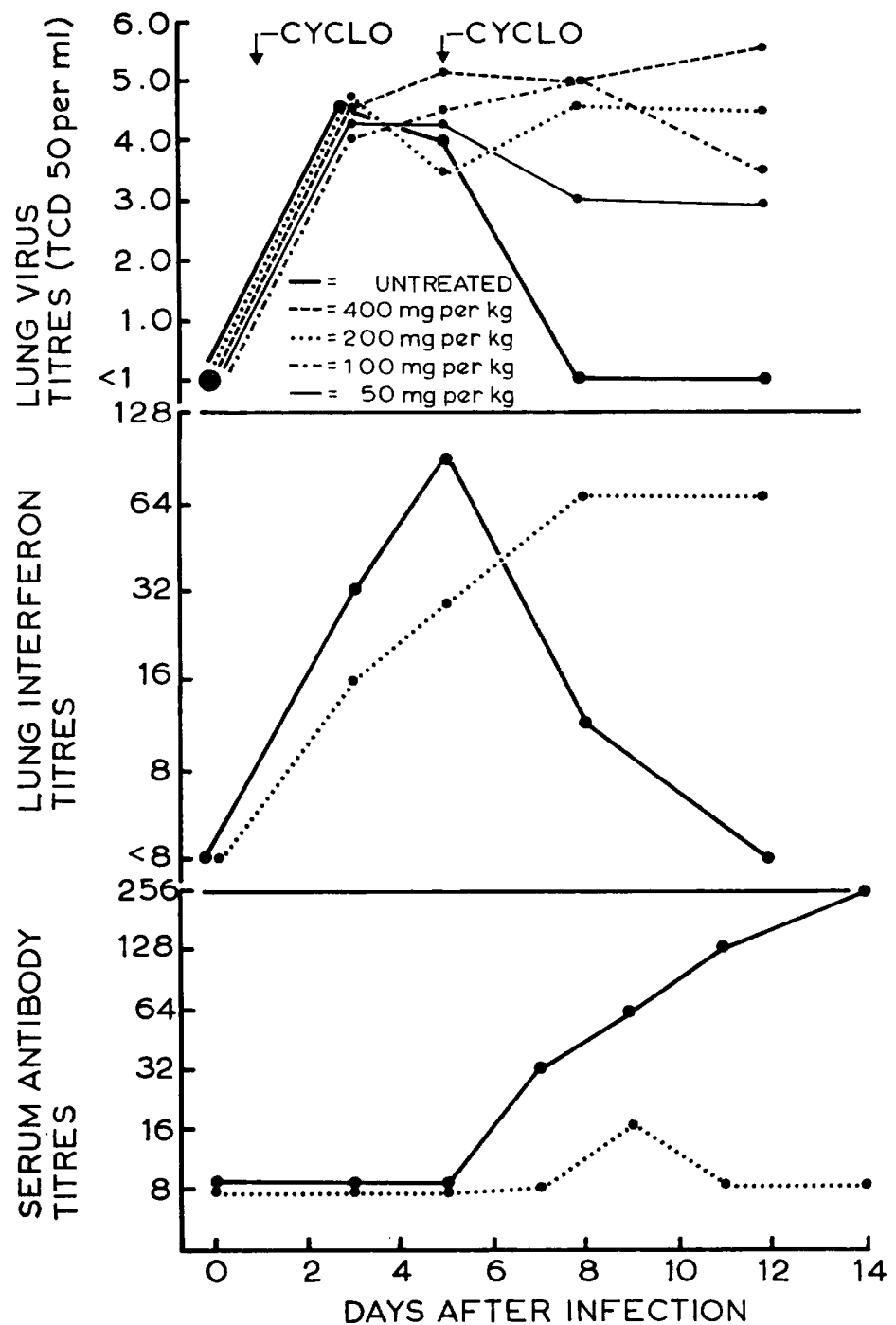

FIG. 8.-The effect of cyclophosphamide on the sequence of events after infection with Sendai virus Cyclophosphamide was given on the 1 st and 5 th days after infection.

It seems likely that the persistence of high concentrations of virus in the lungs after the 5th day was responsible for the pneumonic consolidation.

\section{Interferon assay}

The effects of cyclophosphamide on interferon production are shown in fig. 8. As previously described, cyclophosphamide was found to depress 
interferon production during the first 5 days of the infection (Robinson and Heath). Of particular interest was the finding that, in the treated mice, interferon production continued into the 2 nd wk of the infection whereas in the untreated mice it ceased soon after the disappearance of virus. Interferon was consistently detected in the lungs of the cyclophosphamide-treated mice during the 2 nd $w \mathrm{k}$ of the infection in 3 similar experiments that were

\section{TABLE III}

The effect of cyclophosphamide on the antibody response of mice to Sendai virus infection

\begin{tabular}{c|c|ccccc}
\hline & \multicolumn{5}{|c}{ Mean antibody titre of mouse sera } \\
\hline $\begin{array}{c}\text { Experiment } \\
\text { no. }\end{array}$ & $\begin{array}{c}\text { after infection (day 14) } \\
\text { infection }\end{array}$ & $\begin{array}{c}\text { before } \\
\text { intreated } \\
\text { mice }\end{array}$ & $\begin{array}{c}\text { in mice given cyclophosphamide * } \\
\text { at a dose of (mg per kg) }\end{array}$ \\
\hline 1 & 4 & 64 & 16 & 16 & 16 & 32 \\
\hline 2 & 16 & 128 & -+ & 8 & 16 & 32 \\
\hline
\end{tabular}

* Mice received the stated dose of cyclophosphamide on the 1st and 5th days after infection. $+-=$ No antibody detectable at a serum dilution of 1 in 4 .

carried out. In all of these experiments, the concentration of interferon in the lungs of the treated mice during the 2 nd wk was either the same as or higher than the peak concentration in the lungs of the untreated mice.

It is possible that the early depression of interferon contributed to the prolonged growth of virus in the treated animals, but it is more difficult to understand why the high concentrations of interferon that were present during the $2 \mathrm{nd} \mathrm{wk}$ of the infection were unable to eliminate virus from the lungs.

\section{Antibody assay}

The effect of cyclophosphamide on the antibody response is shown in fig. 8 and table III. It can be seen that the drug always caused some suppression of antibody production. In the experiment recorded in fig. 2 there was no antibody response at all, but a partial response is evident in the data given for the experiments recorded in table III. These results must underestimate the antibody suppression caused by the drug since blood specimens were necessarily obtained from surviving mice. 


\section{White cell count}

Cyclophosphamide was found to depress circulating white cells and the effect was markedly dose-dependent. The results of a typical experiment are shown in table IV; it can be seen that the same effect was obtained in both infected and uninfected mice.

TABLE IV

The effect of cyclophosphamide on 12th-day white cell counts of infected and non-infected mice

\begin{tabular}{l|c|c|c|c|c}
\hline $\begin{array}{c}\text { Experimental } \\
\text { group }\end{array}$ & \multicolumn{4}{|c}{$\begin{array}{c}\text { White cell counts (thousands per mm } \\
\text { on day 12 for mice given cyclophosphamide } \\
\text { at a dose of (mg per kg) }\end{array}$} \\
\cline { 2 - 6 } & 400 & 200 & 100 & 50 & nil \\
\hline Virus-infected & 0.8 & 1.9 & 2.9 & 4.2 & 5.6 \\
Non-infected & 0.6 & 2.0 & 3.0 & 5.6 & 6.6 \\
\hline
\end{tabular}

* Mice received the stated dose of drug on the 1st and 5th days after infection.

\section{Discussion}

There is now increasing evidence that damage to the reticulo-endothelial system, whether caused by disease or drugs, or both, can markedly alter the course of infections caused by several viruses such as those of vaccinia (Kempe, 1960), varicella-zoster (Shanbrom, Miller and Haar, 1960), measles (Mitus et al., 1962) and cytomegalovirus (Symmers, 1960). The results described in this paper indicate that an immunosuppressant drug can also increase the severity of simple virus infection of the upper respiratory tract.

Study of the Sendai virus infection of the mouse lung has revealed that the extensive lung damage that occurs in cyclophosphamide-treated animals is probably due to the failure of the host to bring about early elimination of the virus from the infected tissues. It is well known that cyclophosphamide has a depressant effect on the reticulo-endothelial system. In these experiments, it reduced the numbers of circulating white cells in both infected and non-infected mice, and a striking feature of the lung histology of the infected animals was the paucity of mononuclear cells in the inflammatory exudate. It seems likely therefore that viral elimination is at least partly mediated by these mononuclear cells. How these cells exert this effect is obscure. It is known that they release pharmacologically active substances that are potentially capable of mediating an inflammatory response (Schild and Willoughby, 1967) and the raised temperature, acidity and hypoxia found in the exudate are all known to have antiviral effects (Lwoff, 1959). It is unlikely that this is an important function of the mononuclear cells in this system, because in the cyclophosphamidetreated animals excessive viral replication continues in the severely inflamed 
lungs. It is known that antibody-forming cells are derived from mononuclear cells and it is possible that this is the important antiviral function of these cells. However, it is currently held that antibody plays a relatively unimportant role in the termination of primary virus infections because it is not usually detected in either the blood or infected tissue until after the process of viral elimination has commenced (Isaacs and Hitchcock, 1960; Sydiskis and Schultz, 1966). Since it has been shown that lymphocytes can produce relatively larger amounts of interferon (Gresser, 1961) it is possible that in normal circumstances the mononuclear cells provide a large proportion of the interferon found in the infected tissues and this may be an important antiviral function of these cells. Against this concept are the facts that (i) interferon production occurred early in the untreated mice at a time when few mononuclear cells were present in the infected tissues, and (ii) considerable production of interferon occurred in the treated mice during the $2 \mathrm{nd}$ wk of the infection when the mononuclear response was markedly reduced. The initial depression of interferon production by cyclophosphamide may have been at least partly responsible for the excessive virus growth in the lungs, but it is difficult to understand why the high concentrations of interferon present in these organs late in the infection failed to prevent viral replication. It is clear that further investigation is required to elucidate the mechanisms concerned with recovery from primary virus infections of the respiratory membranes.

Although the concentrations of cyclophosphamide used in these experiments are far in excess of those used in man, our results indicate that immunosuppressant therapy can possibly increase susceptibility to respiratory viral infections with all the further attendant risks of increased susceptibility to bacterial infection.

\section{SUMMARY}

Cyclophosphamide was found to convert the mild Sendai virus infection of mice into a serious and sometimes fatal pneumonic illness, which appeared to be due to the failure of the mice to rid themselves of the infecting virus. The drug was shown to reduce the numbers of circulating white blood cells, to prevent the development of the mononuclear infiltration in the infected lung and to depress antibody production. It produced an initial depression of interferon production, but high concentrations of interferon were found in the lung during the late stages of the infection.

The significance of these findings is discussed in relation to the mechanisms of termination of virus infections and to the potential risk of respiratory disease during immunosuppressant therapy.

We would like to thank Miss G. V. Martin and Mr J. W. Miller for their excellent technical assistance.

\section{REFERENCES}

Gresser, I. . . . . . . . . . . . 1961. Proc. Soc. Exp. Biol. Med., 108, 799.

Haggerty, R. J., AND Eley, R. C. . . 1956. Pediatrics, 18, 160.

Hill, R. B., JR, Dahrling, B. E., II, 1967. Amer. J. Med., 42, 327.

StARzL, T. E., AND RIFKIND, D. 


\section{Cyclophosphamide and Sendai virus infection}

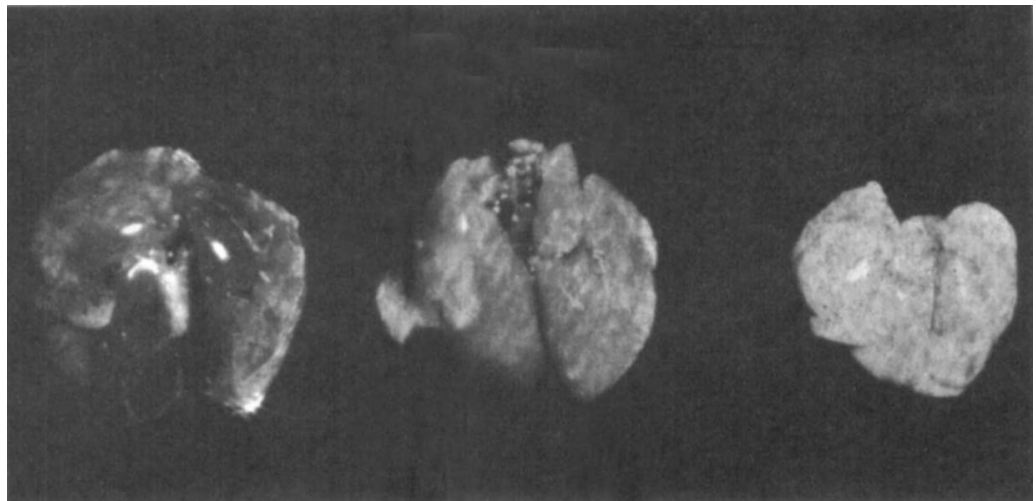

FIG. 1.-Macroscopic appearances of the lungs of mice infected with Sendai virus. Left and centre: lungs from cyclophosphamide-treated animals showing respectively complete and partial consolidation. Right: lungs from an untreated animal showing no abnormality. $\times c .2$.

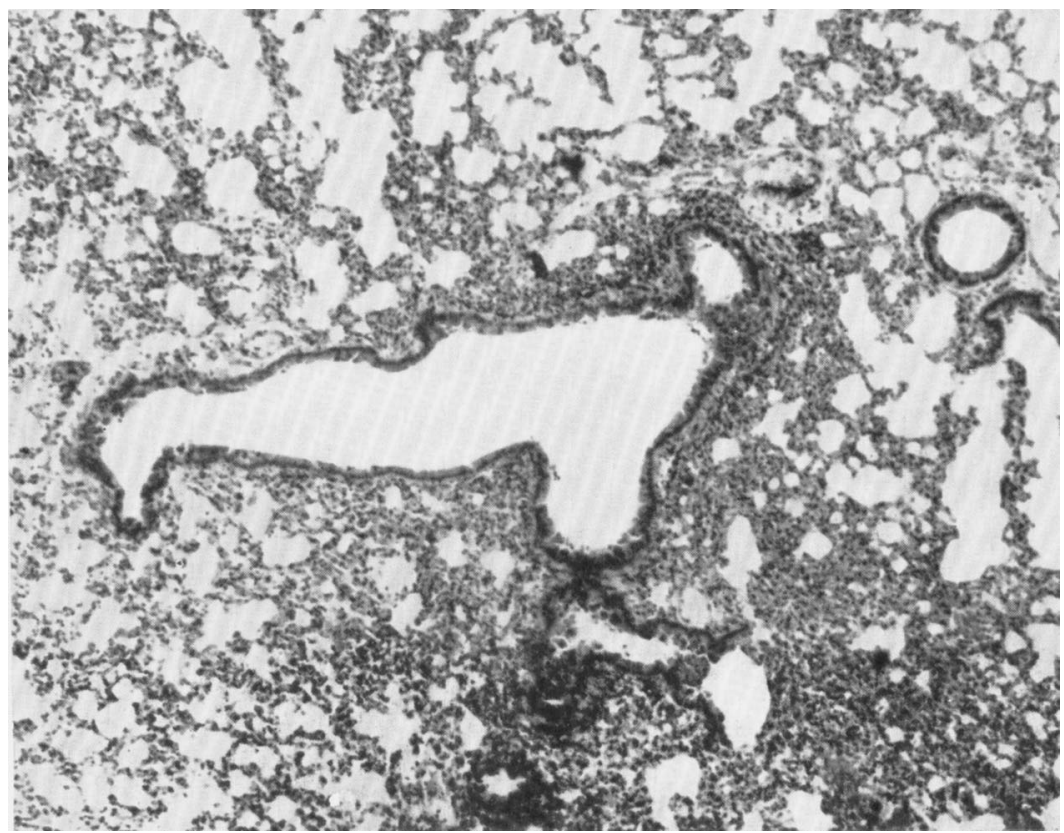

FIG. 2.--Lung, 5 days after infection; cyclosphosphamide treatment. The bronchi show epithelia damage and a mainly polymorphonuclear inflammatory infiltration of moderate intensity. The. alveolar fields show patchy areas of inflammatory reaction. Haematoxylin and eosin (HE). $\times 60$ 
Cyclophosphamide and SEndai Virus INFECTION

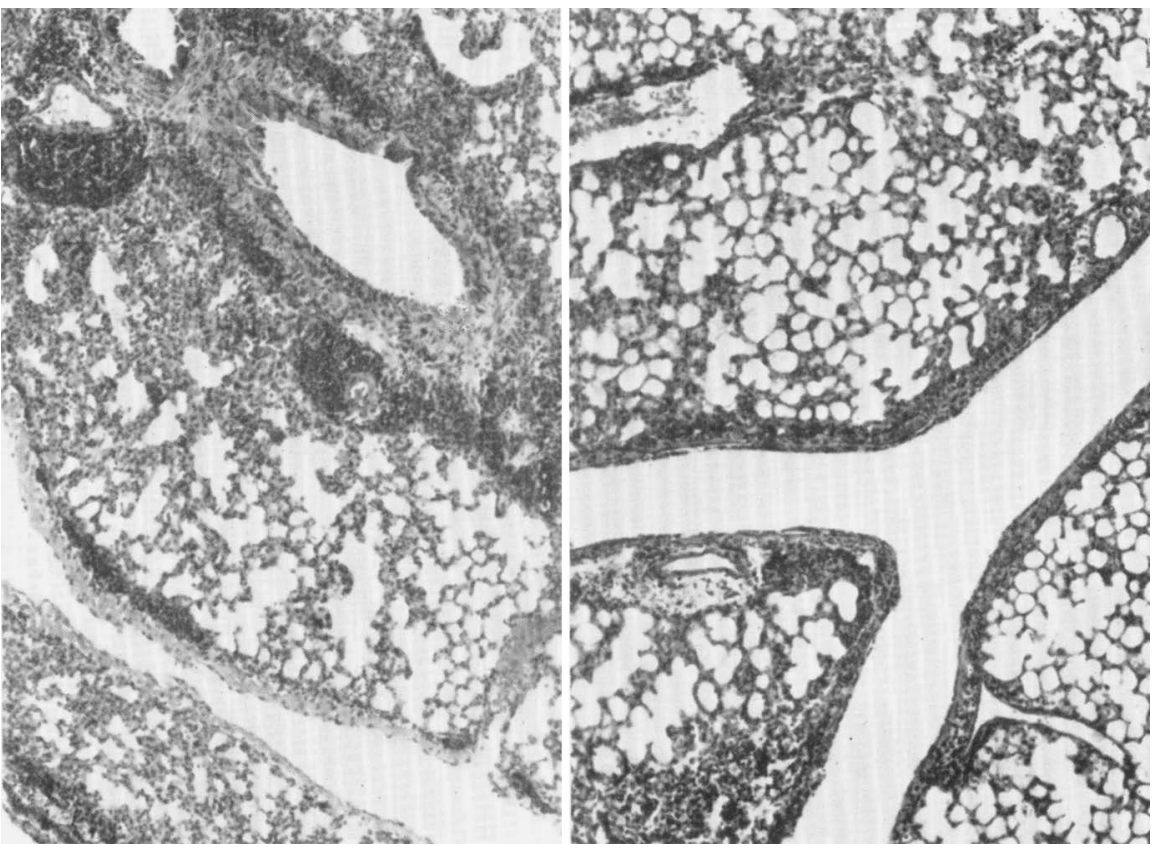

F1G. 3.-Lung, 10 days after infection. A direct comparison between the intense nodular peribronchial mononuclear infiltration seen in untreated animals (left) and the relatively slight and pleomorphic infiltration in the cyclophosphamide-treated mice (right). The alveolar fields were selected to show comparable degrees of inflammatory reaction. HE. $\times 60$.

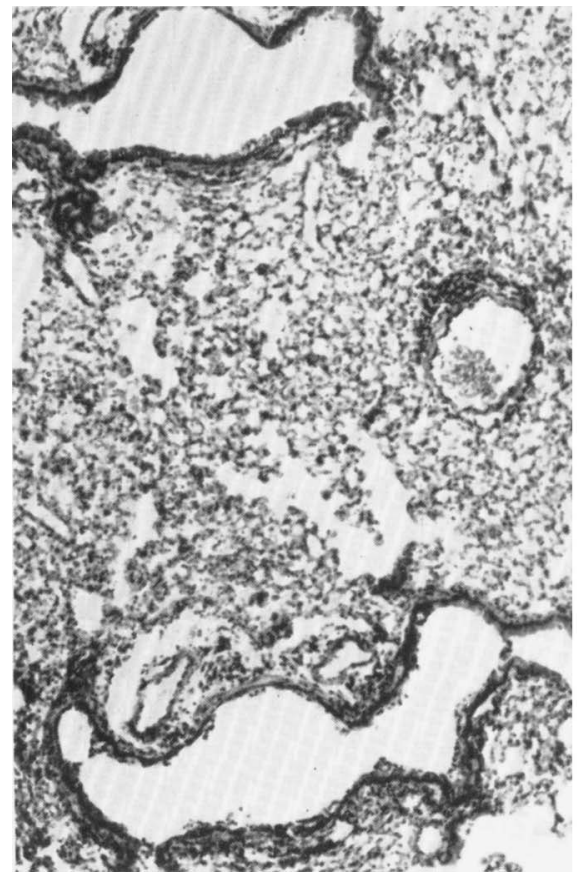

FIG. 4.-Lung, 10 days after infection; cyclophosphamide treatment. There is moderate bronchial damage and more widespread alveolar wall thickening and cellular infiltration. HE. $\times 60$.

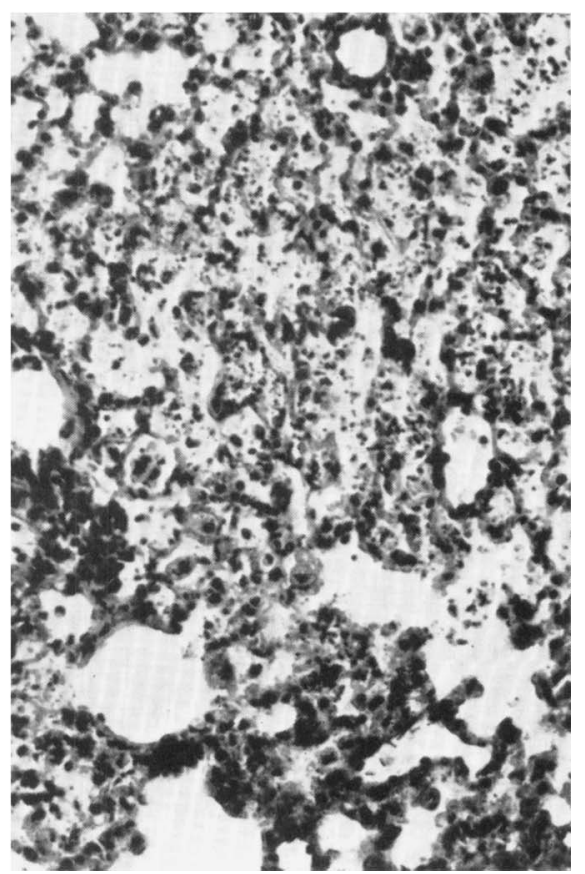

FIG. 5.-Lung, 10 days after infection; cyclophosphamide treatment. The patchy intraalveolar exudate is composed of pyknotic polymorphs and some large mononuclear cells. HE. $\times 150$. 
Cyclophosphamide and Sendal virus infection

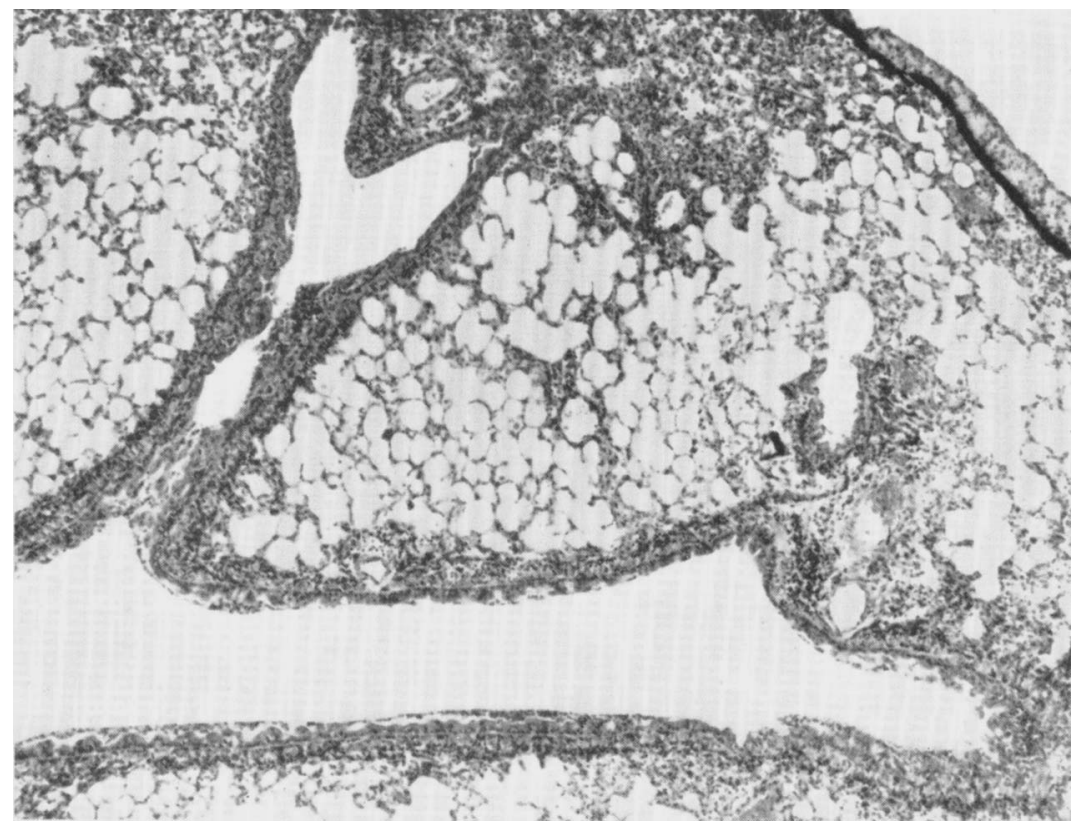

FIG. 6.-Lung, 13 days after infection; cyclophosphamide treatment. Patchy pneumonia and bronchial inflammatory changes with continuing mucosal destruction and polymorphonuclear exudate lining the lumen. A small proportion of the inflammatory cells in and around the bronchi show some pyroninophilia. HE. $\times 60$.

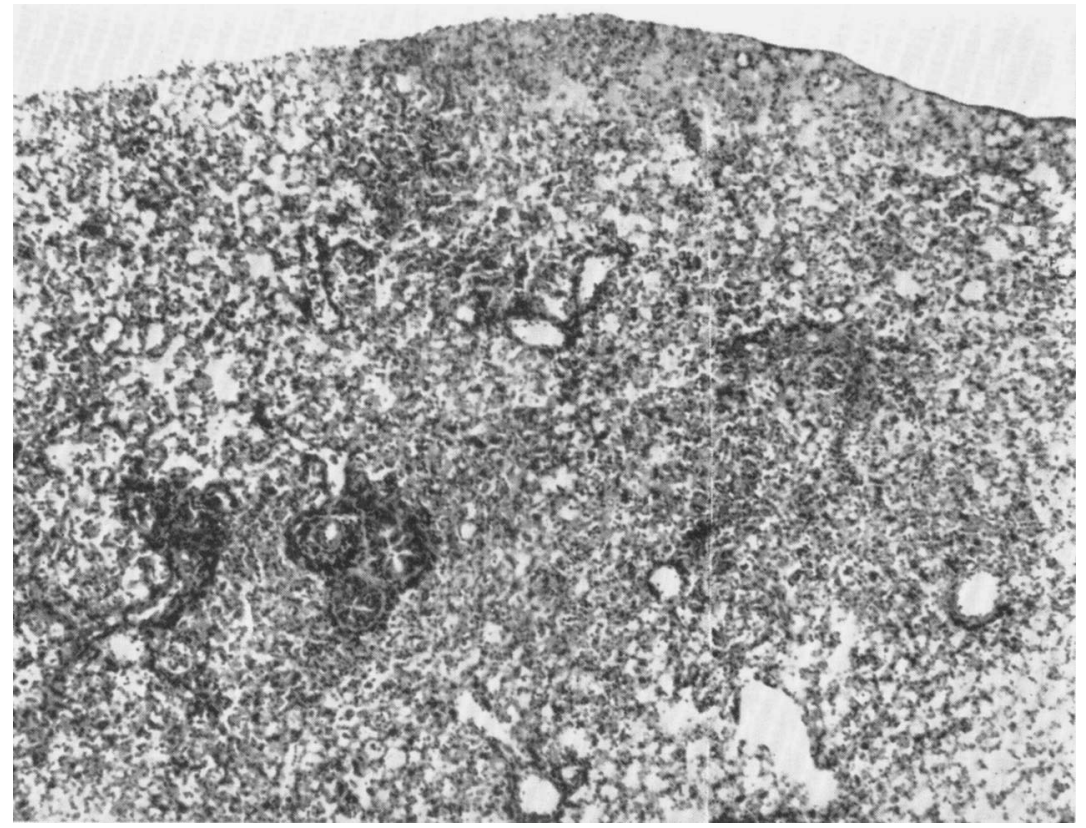

Fig. 7.-Lung, 13 days after infection; cyclophosphamide treatment. Similar bronchial changes and more widespread oedema and pneumonic change. HE. $\times 60$. 
Horsfall, F. L., JR ． . . . . . . . 1939. J. Exp. Med., 70, 209.

ISAACS, A., AND HITCHCOCK, GRISELDA . 1960. Lancet, 2, 69.

Kempe, C. H. . . . . . . . . . . . . 1960. Pediatrics, 26, 176.

LwoFf, A. . . . . . . . . . 1959. Bact. Rev., 23, 109.

Merselis, J. G., JR, KAYE, D., AND 1964. Archs Intern. Med., 113, 679. HoOK, E. W.

Mitus, Anna, Holloway, Ann, Evans, 1962. Amer. J. Dis. Child., 103, 413. AUDREY E., AND ENDERS, J. F.

Robinson, T. W. E., Cureton, R. J. R., 1968. J. Med. Microbiol., 1, 89. AND HEATH, R. B.

Robinson, T. W. E., and Heath, R. B. . 1968. Nature, Lond., 217, 178.

Schild, H. O., AND Willoughby, D. A. 1967. Br. Med. Bull., 23, 46.

Shanbrom, E., Miller, S., ANd HaAr, H. 1960. Ann. Intern. Med., 53, 523.

Stender, H. S., Strauch, D., AND 1961. Strahlentherapie, 115, 175. WINTER, $\mathrm{H}$.

Sydiskis, R. J., ANd Schultz, I. . . 1966. J. Infect. Dis., 116, 455.

Symmers, W. St.C. . . . . . . . 1960. J. Clin. Path., 13, 1. 